\begin{tabular}{|llllllllll}
\hline I & O & II & R & N & A & I & & O & F \\
\hline
\end{tabular}

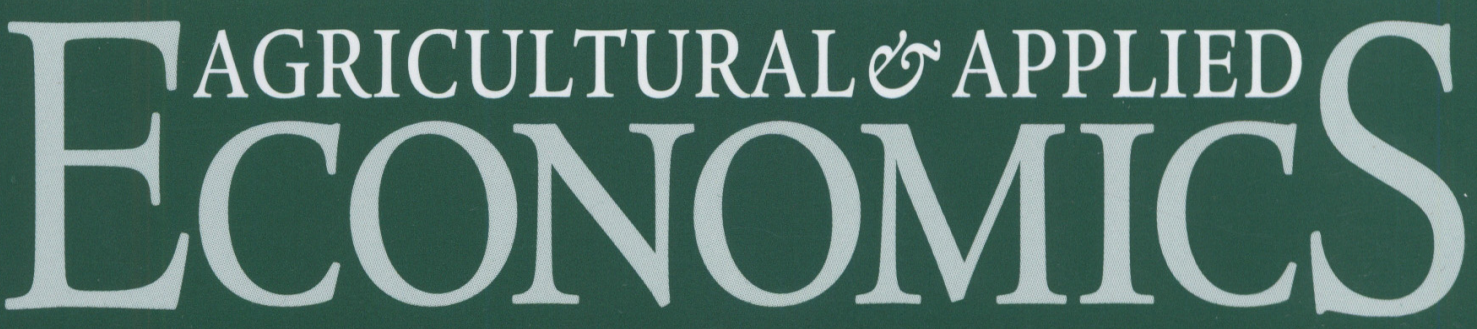

\title{
VOLIIME 44
}

Novemiler 2012

NIMBER 4

Willingness-to-Pay for Beef Quality Attributes: A Latent Segmentation Analysis of Korean Grocery Shoppers / Chanjin Chung, Brian C. Briggeman, and Sungill Han

Evaluation of Market Thinness for Hogs and Pork / Jason R.V. Franken and Joe L. Parcell

Market Power in Poultry Production Contracting? Evidence from a Farm Survey / James M. MacDonald and Nigel Key

The Effect of Distance and Cost on Fruit and Vegetable Consumption in Rural

Texas / Richard A. Dunn, Wesley R. Dean, Cassandra M. Johnson, Andrew Leidner, and Joseph R. Sharkey

Export Demand Elasticity Estimation for Major U.S. Crops / Jeffrey J. Reimer, Xiaojuan Zheng, and Mark J. Gehlhar

From Coffee Beans to Microchips: Export Diversification and Economic Growth in Costa Rica / Gustavo F.C. Ferreira and R. Wes Harrison

Manure Transfers in the Midwest and Factors Affecting Adoption of Manure Testing / Sarah Ali, Laura McCann, and Jessica Allspach

Are Consumers Willing to Pay More for Low-Input Turfgrasses on Residential Lawns? Evidence from Choice Experiments / Chengyan Yue, Kari Hugie, and Eric Watkins

Risk Analysis of Tillage and Crop Rotation Alternatives with Winter Wheat / Jeffery R. Williams, Matthew J. Pachta, Kraig L. Roozeboom, Richard V. Llewelyn, Mark M. Claassen, and Jason S. Bergtold

Tall Fescue Toxicosis Mitigation Strategies: Comparisons of Cow-Calf Returns in Spring- and Fall-Calving Herds / Stephen A. Smith, James D. Caldwell, Michael P. Popp, Kenneth P. Coffey, John A. Jennings, Mary C. Savin, and Charles $F$. Rosenkrans, $J r$.

Forage Response to Swine Effluent: A Cox Nonnested Test of Alternative

Functional Forms Using a Fast Double Bootstrap / Seong C. Park,

B. Wade Brorsen, Arthur L. Stoecker, and Jeffory A. Hattey

Financing Constraints and Access to Credit in a Postcrisis Environment: Evidence from New Farmers in Alabama / Valentina Hartarska and Dennis Nadolnyak 


\title{
EDITORIAL STAFF
}

\section{Editors}

\author{
Mary A. Marchant \\ Virginia Tech \\ Darrell J. Bosch \\ Virginia Tech
}

Associate Editor

\section{Michael Wetzstein \\ University of Georgia}

\section{Editorial Council}

\author{
Giovanni Anania \\ University of Calabria, Italy \\ Jean Paul Chavas \\ University of Wisconsin-Madison \\ Keith Coble \\ Mississippi State University \\ Patricia Duffy \\ Auburn University \\ Keith Fuglie \\ Economic Research Service, USDA \\ Barry K. Goodwin \\ North Carolina State University \\ R. Wes Harrison \\ Louisiana State University \\ Jeffrey L. Jordan \\ University of Georgia
}

\author{
Catherine Kling \\ Iowa State University \\ William Liefert \\ Economic Research Service, USDA \\ Jayson Lusk \\ Oklahoma State University \\ David Pannell \\ University of Western Australia \\ Jutta Roosen \\ Technische Universitaet Muenchen \\ Ted Schroeder \\ Kansas State University \\ Dawn Thilmany McFadden \\ Colorado State University \\ Sophie Thoyer \\ Montpellier Supagro, France
}

\section{EDITORIAL POLICY}

The Journal of Agricultural and Applied Economics (JAAE) provides a forum for creative and scholarly work in agricultural economics and related areas. Contributions on methodology and applications in business, extension, research, and teaching phases of agricultural and applied economics are equally encouraged. Submitted manuscripts are subject to peer review for publication consideration. Submission of critiques or comments on JAAE articles are welcomed.

\section{EDITORIAL COMMUNICATIONS}

Please address editorial correspondence to one of the following co-editors: Darrell Bosch, Department of Agricultural and Applied Economics, Virginia Tech, Blacksburg, VA 24061 (Phone: 540-231-5265, Fax: 540-231-7417, E-mail: bosch@vt.edu) or Mary Marchant, Department of Agricultural and Applied Economics, Virginia Tech, Blacksburg, VA 24061 (Phone: 540-231-1674, Fax: 540-231-7417, E-mail: mary.marchant@vt.edu). Manuscripts should be submitted on-line following the instructions given on the inside back cover of this volume.

The Journal of Agricultural and Applied Economics (ISSN 1074-0708) is published in February, May, August, and November by the Southern Agricultural Economics Association (SAEA). Visit our worldwide web site at http://www.saea.org/jaae/jaae.htm.

Copyright (C) 2012 by the Southern Agricultural Economics Association. Any article or other material published in the $J A A E$ may not be resubmitted for publication or republished elsewhere in full or in part without the written permission of the editors. 


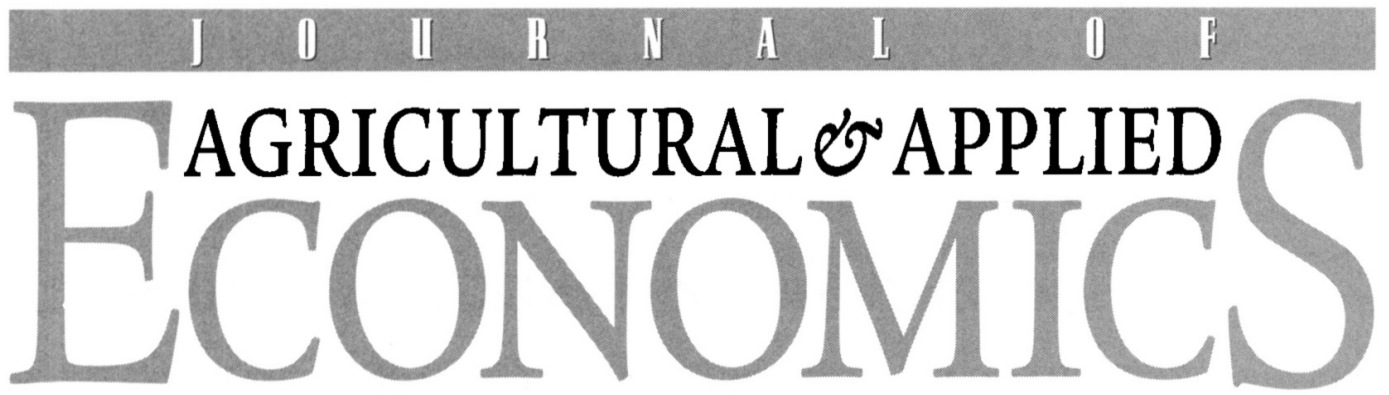

\section{VOLUIME 44}

NOVEMBER 2012

NIMBER 4

Willingness-to-Pay for Beef Quality Attributes: A Latent Segmentation Analysis of Korean Grocery Shoppers / Chanjin Chung, Brian C. Briggeman, and Sungill Han . . . . . . . . . . 447

Evaluation of Market Thinness for Hogs and Pork / Jason R.V. Franken and Joe L. Parcell . . 461

Market Power in Poultry Production Contracting? Evidence from a Farm Survey / James M. MacDonald and Nigel Key . . . . . . . . . . . . . . . . .

The Effect of Distance and Cost on Fruit and Vegetable Consumption in Rural Texas / Richard A. Dunn, Wesley R. Dean, Cassandra M. Johnson, Andrew Leidner, and Joseph R. Sharkey . . . . . . . . . . . . . . . . . . . . . . . . . .

Export Demand Elasticity Estimation for Major U.S. Crops / Jeffrey J. Reimer, Xiaojuan Zheng, and Mark J. Gehlhar.

From Coffee Beans to Microchips: Export Diversification and Economic Growth in Costa Rica / Gustavo F.C. Ferreira and R. Wes Harrison

Manure Transfers in the Midwest and Factors Affecting Adoption of Manure Testing / Sarah Ali, Laura McCann, and Jessica Allspach .

Are Consumers Willing to Pay More for Low-Input Turfgrasses on Residential Lawns?

Evidence from Choice Experiments / Chengyan Yue, Kari Hugie, and Eric Watkins.

Risk Analysis of Tillage and Crop Rotation Alternatives with Winter Wheat / Jeffery R. Williams, Matthew J. Pachta, Kraig L. Roozeboom, Richard V. Llewelyn, Mark M. Claassen, and Jason S. Bergtold.

Tall Fescue Toxicosis Mitigation Strategies: Comparisons of Cow-Calf Returns in Spring- and Fall-Calving Herds / Stephen A. Smith, James D. Caldwell, Michael P. Popp, Kenneth P. Coffey, John A. Jennings, Mary C. Savin, and Charles F. Rosenkrans, Jr. . . . . .

Forage Response to Swine Effluent: A Cox Nonnested Test of Alternative Functional Forms Using a Fast Double Bootstrap / Seong C. Park, B. Wade Brorsen, Arthur L. Stoecker, and Jeffory A. Hattey . . . . . . . . . . . . . . . . . . . . . . . .

Financing Constraints and Access to Credit in a Postcrisis Environment: Evidence from New Farmers in Alabama / Valentina Hartarska and Dennis Nadolnyak. 